\title{
THE ADMINISTRATION OF THE GOVERNMENT OF PEKANBARU CITY FIXED ASSET: THE MIX METHOD APPROACH
}

\author{
Julian $^{1}$, Vince Ratnawati ${ }^{2}$, dan Yesi Mutia Basri ${ }^{3}$ \\ 1,2,3 Program Magister Akuntansi Pasca Sarjana Universitas Riau \\ Gedung Lab. Akuntansi Fakultas Ekonomi Kampus Bina Widya Km. 12,5 Panam-Pekanbaru \\ E-mail : julianjalius@gmail.com \\ diterima: 21/9/2019; direvisi: 8/2/2020; diterbitkan: 26/3/2020
}

\begin{abstract}
This research has a formulation of problems, namely whether the administration of fixed assets in The Government of Pekanbaru City is already run by Permendagri number 19 the year 2016 about the guidelines of regional goods management, and any constraints in the fixed asset administration in the Government of Pekanbaru City. Samples on research with quantitative research methods are 10 OPD that have the largest fixed asset value on audited fiscal year balance 2017. For the method of qualitative research, informants or the speakers in this research are Head of Sub Division of Inventory and Elimination of Assets and Head of Sub Division Development and Evaluation of Regional Financial and Asset Management Agency (BPKAD) Pekanbaru City and Head of General and Personnel Subdivision alongside with Goods Manager in the Department of Education, Department of Public Works and Spatial Planning and Department of Public Housing and Settlement Areas. The method used in the study is a mixed research method with sequential explanatory research design. As for the quantitative method, used quantitative descriptive analysis. While the qualitative method, using the triangulation technique. This research indicates that The Government of Pekanbaru City is implementing fixed asset administration, with details of evaluation of bookkeeping, inventory, and reporting of fixed assets as well as results of the evaluation of document filling completeness, under Permendagri number 19 the year 2016 about the guidelines of regional goods management and The Government of Pekanbaru City faced obstacles in the administration of fixed assets, among others, supporting documents of insufficient fixed assets, the frequent goods manager change/mutation, the migration aspect of SIMDA BMD to SIPKD Asset as an asset management information system, and the lack of fixed asset management regulatory device policy.
\end{abstract}

Keywords: Fixed asset administration, mixed-method approach, bookkeeping, inventory, and fixed asset reporting

\section{INTRODUCTION}

The management of the regional finances must be accountable responsibly and transparently, both to the public and the central government. Management of regional assets is governed by the government regulation of The Republic of Indonesia number 27 the year 2014 which then followed the domestic Permendagri number 19 the year 2016 about the guidelines of regional goods management. By Act No. 28 of 1999 concerning the clean and free state organizers of corruption, collusion, and nepotism, in carrying out the principle of legal certainty, the orderly principle of the State, the principle of public interest, the principle of openness, professional, and accountability. The management of the area belongs to the scope of 1) officials of local goods manager; 2) planning needs and budget; 3) procurement; 4) usage; 5) utilization; 6) safeguards and maintenance; 7) valuing; 8) transfer; 9) destruction; 10) deletion; 11) administration; 12) coaching, supervision, and control; 13) management of regional goods in the SKPDs that uses the financial management pattern of the Regional Public Service Agency; 14) local goods in 
Jurnal Ilmiah Ekonomi dan Bisnis

Vol. 17. No.1, Maret 2020 : 63-71

EISSN : $2442-9813$

ISSN : $1829-9822$

the form of statehouses, and 15) indemnification and sanctions.

On the balance sheet, the presentation of fixed assets is very significant and material. For financial reports to be reasonably present the accuracy of fixed asset data is required. The Financial Audit Board (BPK), with this circumstance, still many pay special attention, especially on the problem of fixed assets.

According to the regulation Permendagri number 19 the year 2016 about the guidelines of regional goods management, chapter I of the general provisions of article 1 point 47, the administration is a series of activities that include bookkeeping, inventory, and reporting of regional goods accordance with the provisions of the regulation. However, there are still weaknesses, such as fixed assets not wellinventoried. There are 4 (four) possibilities, namely: 1) The fixed assets identified and registered. It is an ideal and desirable condition in asset management. Often the fixed assets still found, but the information or identity of the fixed assets not recorded fully. For example, the lack of value of fixed assets and documentation of ownership; 2) The fixed assets identified but not registered. It is still a verdict in the examination of the Financial Audit Board (BPK); 3) The fixed assets not identified but the record exists. This is the most common condition, and usually, it shows that the deletion process is not operating accurately; also the last situation, 4) The fixed assets not identified and in the record also not exist. This can be known from the SP2D issued by the BUD. For example, maintenance costs of fixed assets where these fixed assets are not physically present on the record. (Mustika, 2012)

From the opinion provided by the Financial Audit Board of the report on the examination results (LHP) of the financial statement of the fiscal year 2011 up to 2015, giving a fair opinion with exclusions and unfair opinion on the LHP Financial year budget 2016 to 2018. However, it still provides notes on the management and representation of fixed assets.

Fixed asset Administration research on local governments covering bookkeeping, inventory, and reporting, has been conducted several times and implemented in many of the spreadable areas. Ricardo, who researched in the year 2017 with the title of optimization of fixed Asset management with a soft system methodology approach (case study on financial management bodies and assets of regional Pekanbaru city), which uses interview data collection techniques and documentation, examining the problem of fixed Asset management in the Financial Management Board and the city of regional assets Pekanbaru which has not been optimal in implementation and has not been the update Standard Operating Procedure (SOP) fixed Asset Management under the latest regulations.

Furthermore, the research with the title of Evaluation of the administration of the permanent assets of Padang city government was conducted by Mustika in the year 2012 by applying data collection techniques through interviews, observations, and documentation. The results of the research conclude that the administration of the Government's fixed assets in Padang City has not reached the degree of conformity of $100 \%$, because of the average bookkeeping evaluation, inventory, reporting and completeness document filling results in the maximum degree. Not maximum implementation of administration caused the limitation of data supporting fixed assets, socialization of the regulations on the administration of assets is still weak, human resources limitation, and lack of adequate compensation for welfare employees in the fixed asset administration field. 
Regarding the significance of the asset administration continues to play one of the main roles in one of the elements of regional property management and also still not much research on this field and in many of the spreadable location of research, then the author attempted to further research with the title of the administration of the fixed asset of Pekanbaru City: mix method approach. This research uses a mixed research approach, which is a mix of quantitative and qualitative research methods, which up to now rarely use the mix research method in developing studies on the government fixed asset administration.

\section{LITERATURE REVIEW}

According to the regulation by Permendagri number 19 the year 2016 about the guidelines of regional goods management chapter I of the general provisions of article 1 point 47, the administration is a series of activities that include bookkeeping, inventory, and reporting of regional goods accordance with the provisions of the regulation.

Referring over the Kamus Besar Bahasa Indonesia, the administration derived from the administrative term, noun (nominal), which means the paperwork affair (finance and so on) in the company (state and so on); Administration.

In bookkeeping, list of user goods collected by the fixed assets handler. Based on the list of user goods list, will be compiled a list of local goods by the fixed assets handler concerning for classification and classifications of goods.

Inventory definitions according to Permendagri number 19 the year 2016 about the guidelines of regional goods management, chapter I of the general provisions of article 1 point 48, inventories are an activity to conduct logging, recording, and reporting of fixed asset data collection. In the inventory process, at least in 5 (five) years, the inventory of goods owned by the user of goods, at least 1 (one) time. After the inventory completed, the inventory result report is delivered no later than (three) months by the user of the goods to the fixed assets handler.

In the reporting process, the semester report of goods users and the annual report of the goods users compiled by co-users of goods to then deliver to the user of the goods. Furthermore, based on the semester report of goods users and the annual report of the goods users compiled by co-users of goods will draft in the semester report of goods users and the annual report of the goods users. In the preparation of SKPD balance sheet, the semester report of goods users and the annual report of the goods users is used as the source document and, next will be carried to the fixed assets handler. The semester report of goods and the annual report of the goods report compiled by the fixed assets handler after the semester report of goods users and the annual report of the goods users compiled by cousers of goods. The report of the semester report of goods users and the annual report of the goods users, on the next, will use to compile reports of regional goods. Local Government balance sheet using reports of regional goods in the drafting process to present the value of fixed assets.

This research is reviewing the fixed asset administration evaluation namely the implementation of the bookkeeping, inventory, and reporting of fixed assets, and the evaluation of the completeness of the filing of documents in the administration. (Mustika, 2012).

Fixed assets, according to the definition of the Government Accounting Standards Committee contained in the Technical bulletin No. 15, Chapter I Introduction, 1.1 background, line 15 , is a tangible asset that has a period of more 
Jurnal Ilmiah Ekonomi dan Bisnis

Vol. 17. No.1, Maret 2020 : 63-71

EISSN : $2442-9813$

ISSN : $1829-9822$

than 12 (twelve) months to be used in Government activities or utilized by the general public consisting of land, equipment and machinery, buildings and buildings, roads, irrigation and networks, other fixed assets, and construction in workmanship. Meanwhile, according to the regulation of Permendagri number 19 the year 2016 about the guidelines of regional goods management, these not state in detail about the definition of fixed assets, but in general, any assets, whether fixed assets or stock items referred to local goods (BMD), hereinafter in Article 1 chapter I General Provisions, has the intention of all goods purchased or obtained at the expense of the APBD or derived from other legitimate acquisition. Accordingly, under the definitions described above, fixed assets are part of the regional property (BMD), under the criteria that have displayed in the technical bulletin No. 15 issued by the Accounting Standards Committee Government.

\section{METHOD}

This research uses a mixed research method by collecting data through interviews, observations, and documentation to be evaluated according to predefined criteria. The combination research method used in this research is the method of model combination or sequential design explanatory. Sugiyono (2014:486), said that the method of a combination of a design research method combines quantitative and qualitative research methods sequentially, were in the first stage of research done using quantitative methods, and at the second stage is done by the qualitative method. The quantitative method used a quantitative descriptive analysis. While the qualitative method plays a role in strengthening, expanding and deepening the quantitative data that has been obtained in the previous stage, using a triangulation technique that consists of interview techniques, documentation, and observation in the compilation of the proposed data. Both methods of analysis are used to compare the appropriateness between the implementation of administration in The Government of Pekanbaru City, with the administration based on the regulation of Permendagri number 19 years 2016 on the guidelines of regional goods management.

In the quantitative method, the population in this study was 47 (fortyseven) Regional Organizations (OPDs) located in the Government of Pekanbaru City. Samples on research with quantitative research methods are 10 OPDs that have the largest fixed asset value on audited fiscal year balance 2017. In this study, the aspect studied was the administration of the fixed assets implemented in the Government of Pekanbaru City based on Permendagri number 19 the year 2016. According to Permendagri number 19 the year 2016 about the guidelines of regional goods management, chapter I of the general provisions of article 1 point 47, the administration is a series of activities that include bookkeeping, inventory, and reporting of regional goods under the provisions of statutory regulations.

Evaluation is done by comparing the implementation of fixed asset administration in The Government of Pekanbaru City with Permendagri number 19 the year 2016, then the assessment and calculated in the form of percentages so that the index will generate that provides information on the level of conformity of the fixed asset administration procedures in the city of Pekanbaru with prevailing laws and regulations. So, the index in this research is a number that shows the comparison of criteria set by legislation.

The evaluation of The Government's fixed asset administration held in 2 (two) sections, namely the bookkeeping, inventory, and reporting of 
the permanent asset of the city government Pekanbaru, and the evaluation of the completeness of documents.

In the analysis of quantitative descriptive data on this study, the level of conformity in this evaluation calculated using a descriptive percentage technique that namely technical analysis, by making a percentage of the existing data, then described. The calculation is dividing the total value obtained by the total criteria that multiplied by 100 (onehundred) percent, so it can present as follows:

Compliance level $=\frac{\text { Total value earned }}{\text { Total } \text { criteria }} \times 100 \%$

Then, the assessment of the overall level of conformity achieved will do. In this study use the following conformity criteria (Widyaningrum, 2010 in Mustika, 2012):

- Criteria 'very suitable', if it reaches $81-100 \%$ compliance.

- Criteria 'suitable', if it reaches 61-80\% compliance.

- Criteria ' fair suitable', if it reaches 41-60\% compliance.

- Criteria 'lack suitable', if it reaches $21-40 \%$ compliance.

- Criteria 'very lack suitable', if it reaches $0-20 \%$ compliance.

Qualitative research methods in this research are types of qualitative research case studies. Informants or the speakers in this research are Head of Sub Division of Inventory and Elimination of Assets and Head of Sub Division Development and Evaluation of Regional Financial and Asset Management Agency (BPKAD) Pekanbaru City and Head of General and Personnel Subdivision alongside with goods manager in the Department of Education, Department of Public Works and Spatial Planning and Department of Public Housing and Settlement Areas.
Sugiyono (2014:403) states that the data analysis process takes place at 2 (two) stages, namely: a). Prior analysis in the field. The data analyzed is the result of preliminary study, or secondary data, which is then used to produce research focus; b). Analysis of the progress the field Miles and Huberman' Model. Miles and Huberman (1984) in Sugiyono (2014.404) suggests that in obtaining saturated data, qualitative data analysis is carried out in an interactive and ongoing manner to complete.

The data collection techniques used in this study are triangulation techniques. Sugiyono (2014) says that the triangulation technique means that researchers use different data collection techniques to obtain data from the same source.

\section{RESULT AND DISCUSSION}

Quantitative Method Data Testing Results.

The bookkeeping evaluation, inventory, and reporting of government fixed asset The Government of Pekanbaru City

The calculation of the percentage level of conformity from the evaluation of fixed asset bookkeeping indicates a figure of $86 \%$ (rounding). This reveals the degree of suitability 'very suitable' with the regulation of the Permendagri number 19 the year 2016. The calculation of the percentage level of conformity from the evaluation of the fixed asset inventory shows a figure of $57 \%$ (rounding), so the degree of conformity is 'fair suitable ' with the regulation of the Permendagri number 19 the year 2016. The percentage of conformity level from the evaluation of the implementation of fixed asset reporting shows the number $91 \%$ (rounding), so the degree of conformity 'very suitable' with the of the Permendagri number 19 the year 2016. 
Jurnal Ilmiah Ekonomi dan Bisnis

Vol. 17. No.1, Maret 2020 : 63-71

EISSN : $2442-9813$

ISSN : $1829-9822$

The level of conformity on the bookkeeping, inventory and reporting aspects on average in the Government of Pekanbaru City fixed assets is only $79 \%$. It meets the criteria 'suitable'. This means the Government of Pekanbaru City has not fully implemented Permendagri number 19 the year 2016 about the guidelines of regional goods management comprehensively.

Evaluation of document filling completeness.

Evaluation in this stage carried out by assessing the completeness of the document of goods inventory card (KIB), which is the basis in the administration of fixed assets. Once obtained conformity level goods inventory card (KIB) A for land amounted to $91 \%$, goods inventory card (KIB) $\mathrm{B}$ for equipment and machinery worth $99 \%$, goods inventory card (KIB) $\mathrm{C}$ for buildings and buildings by $78 \%$, item inventory card ( KIB) D for roads, irrigation and networks valued at $48 \%$, goods inventory card (KIB) $\mathrm{E}$ for other assets of $73 \%$ and goods inventory card (KIB) $\mathrm{F}$ for construction in the works worth $74 \%$, then can be obtained calculation of the level of conformity on Evaluation of the completeness of the fixed asset administration document just only worth $76 \%$ and is in the category of 'suitable' with Permendagri number 19 the year 2016 about the guidelines of regional goods management.

The evaluation of fixed asset administration

After obtaining the average calculation result of the level of conformity on the bookkeeping evaluation, inventory, and reporting of fixed assets of $79 \%$ and the average level of conformity on the evaluation of the fixed assets administration document worthy $76 \%$. On average, the level of conformity obtained from the above calculations, amounting to $78 \%$ that suggests that, in general, the administration of the fixed asset in The Government of Pekanbaru City only reached in the category of 'suitable' in terms of implementing the Permendagri number 19 the year 2016 about the guidelines of regional goods management.

Qualitative Method Data Testing Results

Supporting documents of insufficient fixed assets

Supporting documents of fixed assets are holding so that the value of the fixed assets presented in the asset report is reliable and accounted for. As for the manager of goods as the regional management office, still, find difficulties in the field in obtaining information and supporting documents related to the fixed assets under its management. Implementation of the fixed asset administration the Government of Pekanbaru City, especially in the process of filling the inventory card of goods (KIB) still found constraints to fill it with complete because of the difficulty of obtaining a document supporting the fixed assets its existence has long and is no longer known who save the manuscript of the document and how the status.

The frequent goods manager change/mutation

The manager of the goods as a part of the regional goods management plays an important role in the administration of fixed assets often does changes or mutations. This can be triggered, including information and history of fixed assets on the OPD, whether it is a chronological, event, news, contract, or other document supporting to record other fixed assets if the handover of the position and the work is not complete. 
The migration aspect of SIMDA BMD to SIPKD Aset as an asset management information system.

In the fiscal year 2014, The Government of Pekanbaru City in cooperation with BPKP representatives of Province of Riau using the application of the BMD SIMDA to manage BMD, especially the administration of fixed assets. In the fiscal year 2018, The Government of Pekanbaru City decided to migrate to SIPKD Aset. The migration activities initiated from the socialization of the application of SIPKD assets that which began around the end of the fiscal year 2018, precisely 19-21 December 2018. The Government of Pekanbaru City conducts technical guidance for the goods managers in SKPD to solidify and improve the ability of administration officials, the goods managers and operators in implementing the application SIPKD Aset to support of SIMDA Barang migration to SIPKD Aset. The limited-time preparation to learn new applications coincided with the arrangement of the annual financial statements, of course, this raises a little more constraints.

The lack of fixed asset management regulatory device policy.

In managing the regional property (BMD), The Government of Pekanbaru City use government Regulation (PP) No. 27 the year 2014 on the management of state/local goods and regulation of Permendagri number 19 the year 2016 about the guidelines of regional goods management as a reference in the management of the BMD. Besides, The Government of Pekanbaru City previously also established regional regulation (Perda) No. 14 the year 2008 on the management guidelines of The Government of Pekanbaru City regional goods. The Perda was revoked because it was not per provisions in PP No. 27 the year
2014. The proposed amendment of Perda still done and will be included in the national legislation program (Prolegnas) year 2017, but until the fiscal year 2019, the Perda is still in the discussion level at the regional Board of Representatives. The regulatory policy device of fixed asset management will facilitate and establish the fixed asset administration in The Government of Pekanbaru City. The absence of regulatory policy devices of local goods management, especially the administration of fixed assets, of course, is influential in enforcing the rules and the fixed asset Administration guidelines according to the needs and conditions contained in the OPD in The Government of Pekanbaru City.

\section{CONCLUSIONS AND SUGGESTION}

The conclusion to the research, likely: (1) The Government of Pekanbaru City implementing the fixed asset administration under regulation by Permendagri number 19 the year 2016 about the guidelines of regional goods management where the achievement of conformity level with the details evaluation, inventory, and reporting of assets has obtained the level of conformity only in the category of 'suitable'. The results of the evaluation of the document that indicates the level of conformity and is in the category that also just 'suitable' to the regulation of Permendagri number 19 the year 2016 about the guidelines of regional goods management; and (2) In the implementation of the fixed asset administration, The Government of Pekanbaru City faced obstacles, among others, supporting documents of insufficient fixed assets, the frequent goods manager change/mutation, the migration aspect of SIMDA BMD to SIPKD Aset as an asset management information system, and the lack of fixed asset management regulatory device policy.

This study recommended suggestions, among others: (1) Subsequent 


\section{Jurnal Ilmiah Ekonomi dan Bisnis}

Vol. 17. No.1, Maret 2020 : 63-71

EISSN : $2442-9813$

ISSN : $1829-9822$

research can use analysis and make this research refers to be developed by using quantitative research methods so that the findings on the research results can be tested and generalized. Subsequent research to thoroughly research for each regional organizations (OPDs) existing in quantitative research, and with the informants or speaker other than the Head of Sub Division of Inventory and Elimination of Assets and Head of Sub Division Development and Evaluation of Regional Financial and Asset Management Agency (BPKAD) Pekanbaru City and Head of General and Personnel Subdivision alongside with Goods Manager in OPD, also may be considered necessary to involve Head of OPD as a user of goods, head of Regional Asset Management Organization district as the officer of The Goods Administration, District Secretary as the Goods Manager, or if demanded, The Regional Head as the holder of regional Property Management Power (BMD) as a resource or informer for qualitative research; (2) Further research that craves to discuss regional goods may focus on the management of regional goods according to Permendagri number 19 the year 2016 about the guidelines of regional goods management, other than administration, but also has the scope of the management of regional goods starting from planning needs and budget, procurement, usage, utilization, safeguards, and maintenance, valuing, transfer, destruction, deletion, and also coaching, supervision, and control and (3) Correlated research in the future should take longer research time range so that the research results obtained become more extensive, impeccable and comprehensive.

\section{REFERENCES}

Abdul Halim dan Muhammad Syam Kusufi., 2012, Akuntansi sektor publik, akuntansi keuangan daerah. Salemba Empat, Jakarta.

Cooper Donald, R, Schindler, Pamela S., 2007, Business research methods, Mc Graw-Hill, Irwin, Boston.

Cooper, Harris., 2010, Research synthesis and meta-analysis, Sage, Los Angeles.

Cresswell, Gohn W., 2012, Educational research, Pearson, New York.

Herlina Widyaningrum., 2010, Evaluasi prosedur akuntansi aset tetap (Studi kasus pada Dinas Pendidikan, Pemuda dan Olahraga Kabupaten Magelang), Program Magister Akuntansi, Fakultas Ekonomika dan Bisnis, Universitas Gadjah Mada, Yogyakarta.

Irwan Taufiq Ritonga., 2010, Reviu laporan keuangan pemerintah daerah, lembaga kajian manajemen pemerintah daerah, Yogyakarta.

Kementerian Dalam Negeri Republik Indonesia, Peraturan Menteri Dalam Negeri Nomor 64 Tahun 2013 tentang Penerapan Standar Akuntansi Pemerintahan Berbasis Akrual pada Pemerintah Daerah, Jakarta.

Kementerian Dalam Negeri Republik Indonesia, Peraturan Menteri Dalam Negeri Nomor 19 Tahun 2016 tentang Pedoman Pengelolaan Barang Milik Daerah, Jakarta.

Komite Standar Akuntansi Pemerintahan, 2007, Buletin Teknis Nomor 15 tentang Akuntansi Aset Tetap Berbasis Akrual. Jakarta. 
Rasyidah, Mustika., 2012, Evaluasi

penatausahaan aset tetap

Pemerintah Kota Padang,

Program Magister Akuntansi,

Fakultas Ekonomika dan Bisnis,

Universitas Gadjah Mada,

Yogyakarta.

Miles, M. B., Huberman, A. M., 1984, Quailitative data analysis: a sourcebook of new methods, Sage Publications Inc., California

Peraturan Pemerintah (PP) Nomor 27 Tahun 2014 tentang Pengelolaan Barang Milik Negara/Daerah, Jakarta.

Ricardo., 2017, Optimalisasi pengelolaan aset tetap dengan pendekatan soft system methodology (Studi kasus pada Badan Pengelolaan Keuangan Dan Aset Daerah Kota Pekanbaru), Program Magister Akuntansi, Fakultas Ekonomi dan Bisnis, Universitas Riau, Pekanbaru.

Sugiyono. 2014, Metode penelitian manajemen, Penerbit CV. Alfabeta, Bandung.

Undang-Undang Nomor 28 Tahun 1999 tentang Penyelenggara Negara Yang Bersih Dan Bebas Dari Korupsi, Kolusi dan Nepotisme. 